\title{
ECOLOGICAL STUDIES OF AN EPIKARST COMMUNITY IN SNEŽNA JAMA NA PLANINI ARTO - AN ICE CAVE IN NORTH CENTRAL SLOVENIA
}

\author{
EKOLOŠKE RAZISKAVE EPIKRAŠKE ZDRUŽBE V SNEŽNI JAMI \\ NA PLANINI ARTO - LEDENI JAMI V SEVERNI OSREDNJI \\ SLOVENIJI
}

Federica PAPI ${ }^{1} \&$ Tanja PIPAN ${ }^{2}$

\begin{abstract}
UDC 574.1:551.444.6(497.4)

Federica Papi \& Tanja Pipan: Ecological studies of an epikarst community in Snežna jama na planini Arto - an ice cave in north central Slovenia

Epikarst biodiversity in relation to environmental conditions was studied for the first time in an ice cave, Snežna jama na planini Arto on Mt. Raduha in north central Slovenia. In this alpine cave five sampling sites were monitored for fauna in percolation water in the period of one year. Temperature, conductivity, discharge, $\mathrm{pH}$, total hardness and concentrations of various ions (calcium, chloride, nitrite, sulphate and phosphate) of water were measured. At the entrance of the cave ice is present all year round and the temperature inside the cave rises to a maximum of $4{ }^{\circ} \mathrm{C}$. These circumstances are reflected in the fauna found in percolating water. The first sampling site in the permanent ice was without fauna, as did the sampling site in an area with moonmilk. In the other three sampling sites, individuals of ten invertebrate taxa were found, Copepoda being the most abundant. Their abundance was positively correlated with discharge, $\mathrm{pH}$ and temperature of percolation water and additionally in the most abundant drip also with conductivity and total hardness. High proportion of immature copepods in drips shows that epikarst is their primary (i.e. source) habitat. Investigations of the alpine epikarst fauna can help to understand better the ecology of the epikarst fauna and its roles within the large range of different shallow subterranean habitats.
\end{abstract} Keywords: epikarst, ice cave, percolating water, speleobiology, fauna.
Izvleček

UDK 574.1:551.444.6(497.4)

Federica Papi \& Tanja Pipan: Ekološke raziskave epikraške združbe v Snežni jami na planini Arto - ledeni jami v severni osrednji Sloveniji

V ledeni jami Snežna jama na planini Arto na Raduhi smo opravili prvo raziskavo epikraške biodiverzitete v visokogorskih jamah v povezavi z okoljskimi dejavniki. $\mathrm{V}$ tej visokogorski jami smo eno leto vzorčevali favno na petih mestih. V prenikli vodi smo merili temperaturo, prevodnost, pretok, $\mathrm{pH}$, celokupno trdoto in koncentracije različnih ionov (kalcij, kalij, nitrat, sulfat in fosfat). $\mathrm{V}$ vhodnem delu jame je led prisoten vse leto. Temperatura $\mathrm{v}$ jami ne preseže $4{ }^{\circ} \mathrm{C}$. Te razmere se odražajo $\mathrm{v}$ favni, najdeni v prenikli vodi. Prvo vzorčno mesto je bilo ves čas zaledenelo in brez favne, brez živali je bilo tudi vzorčno mesto $\mathrm{z}$ jamskim mlekom na stropu. Na drugih treh vzorčnih mestih so bili najdeni osebki desetih nevretenčarskih taksonov, med katerimi so bili najštevilčnejši kopepodni rakci. Njihova abundanca je bila $\mathrm{v}$ pozitivni korelaciji s pretokom, $\mathrm{pH}$ in temperaturo ter $\mathrm{v}$ curku $\mathrm{z}$ najštevilčnejšo favno tudi s prevodnostjo in celokupno trdoto. Velik delež mladih kopepodov v vzorcih nakazuje, da je epikras njihov primarni (to je izvorni) habitat. Raziskave visokogorske epikraške favne lahko pripomorejo $\mathrm{k}$ celovitejšemu razumevanju ekologije epikraške favne in njene vloge v različnih plitvih podzemeljskih habitatih.

Ključne besede: epikras, ledena jama, prenikajoča voda, speleobiologija, favna.

\footnotetext{
${ }^{1}$ University of Nova Gorica, Vipavska cesta 13, SI-5000 Nova Gorica, Slovenia, e-mail: federicapapi@hotmail.com

${ }^{2}$ Karst Research Institute ZRC SAZU, Titov trg 2, SI-6230, Postojna, Slovenia, e-mail: pipan@zrc-sazu.si
}

Received/Prejeto: 15.5.2011 


\section{INTRODUCTION}

During the Pleistocene period, the Slovene Alps were covered by permanent snow and ice. In the coldest period of the Würmian, the permanent snow line was between $1300-1500 \mathrm{~m}$ above the present sea level and long valley glaciers descended down to $500 \mathrm{~m}$ (Kranjc 1984).

Systematic investigation of the epikarst fauna (fauna from unsaturated zone including deep soil root zone) in Slovenian Alpine or Pre-Alpine caves has not yet been done. There are some sporadic reports on the terrestrial fauna from caves in the Slovenian Alps (e.g., Novak \& Kuštor 1983; Novak et al. 2004; Slapnik 2001), but none on the aquatic cave fauna.

Epikarst is the uppermost layer of karstic bedrock. It is typically $3-10 \mathrm{~m}$ deep, but its characteristics can vary considerably (Ford \& Williams 2007). From an ecological point of view, epikarst is both an exceptionally diverse and environmentally heterogeneous habitat (Culver \& Pipan 2009). Environmental conditions in epikarst are more variable than in caves, and organic carbon dripping from epikarst is an important source of carbon in many caves. The fauna is both diverse and specialized, with Copepoda and, to a lesser extent, Insecta and Amphipoda dominating (Pipan 2005; Pipan et al. 2006). The epikarst aquatic fauna is by far the best known from Dinaric karst in Slovenia (Pipan 2003, 2005) and from patches of isolated karst in Slovenia (Pipan et al. 2008). It has also been studied in other countries, including Spain, Romania, and USA (e.g., Camacho et al. 2006; Moldovan et al. 2007; Pipan \& Culver 2005).

In Slovenia, karst areas comprise $43 \%$ of the state (Knez \& Kranjc 2009), of which about one third (17\%) belongs to the alpine karst (Habič 1969). Precipitation in the alpine karst varies between 1500 to more than $3000 \mathrm{~mm}$ annually and snow cover lasts up to 200 days (Kunaver 1983). Present permanent snow line is at $2700 \mathrm{~m}$ a.s.l. (Kunaver 1983). Summer mean temperature in the Alps is about $11^{\circ} \mathrm{C}$, while winter mean temperature is about $-1.6^{\circ} \mathrm{C}$ (Gams 1960).

The Slovenian calcareous Alps are $100 \mathrm{~km}$ long (from west to east) and $40 \mathrm{~km}$ wide (from north to south) (Kranjc 1984). Dominant rocks are Triassic limestones and dolomites, up to1,000 $\mathrm{m}$ thick, and the highest peak is $2,864 \mathrm{~m}$ in the Julian Alps (Audra et al. 2007). The Slovenian Alps consist of two large formations: the Central Alps (Karavanke) and the Southern Limestone Alps (Julian and Kamnik-Savinja Alps). In the Limestone Alps the great majority of the terrain is built of carbonate rocks and there are a few patches of other rocks. In the Karavanke it is just the opposite - most of the terrain is impermeable rocks and among them there are some carbonate rocks, nearly all of Mesozoic age (Kranjc 1984).

In this contribution, we deal with the drip fauna of the ice cave Snežna jama na planini Arto, in the Southern Limestone Julian Alps, where we intensively studied both the copepod and non-copepod fauna from a series of five epikarst drips. We hypothesized that an alpine epikarst fauna consists mostly of troglobiotic species, but is less diverse and abundant than the epikarst fauna from the Dinaric karst. We ask: (1) Is copepod abundance and diversity correlated with different physical and chemical parameters measured in percolation water? (2) What is a proportion of immature copepod individuals relative to the number of adults as a measure of reproduction? (3) What environmental parameters are correlated with the presence of reproducing copepods?

\section{RESEARCH AREA}

The investigations were carried out in the tourist cave Snežna jama na planini Arto (Cadastre Number 1254, Cave cadastre IZRK ZRC SAZU and Speleological Association of Slovenia) in the north central part of Slovenia (Fig. 1). The cave is situated on Mt. Raduha in the north eastern part of the Kamnik-Savinja Alps (Zupan Hajna et al. 2008). Snežna jama which means "Snow cave" is the largest horizontal cave $(1,327 \mathrm{~m})$ in Mt. Raduha. The cave is developed in the Upper Triassic limestones (Zupan
Hajna et al. 2008). The official entrance is at the one of four large shafts, opening at 1,556 $\mathrm{m}$ a.s.l. and leading into the first cave section-a large gallery. Permanent ice is formed at the entrance part of the cave due to cold air which flows through the shafts into the cave (Zupan Hajna et al. 2008). Maximum temperature inside the cave is $4{ }^{\circ} \mathrm{C}$. In the inner part of the cave there are flowstone deposits and moonmilk (Fig. 2). 

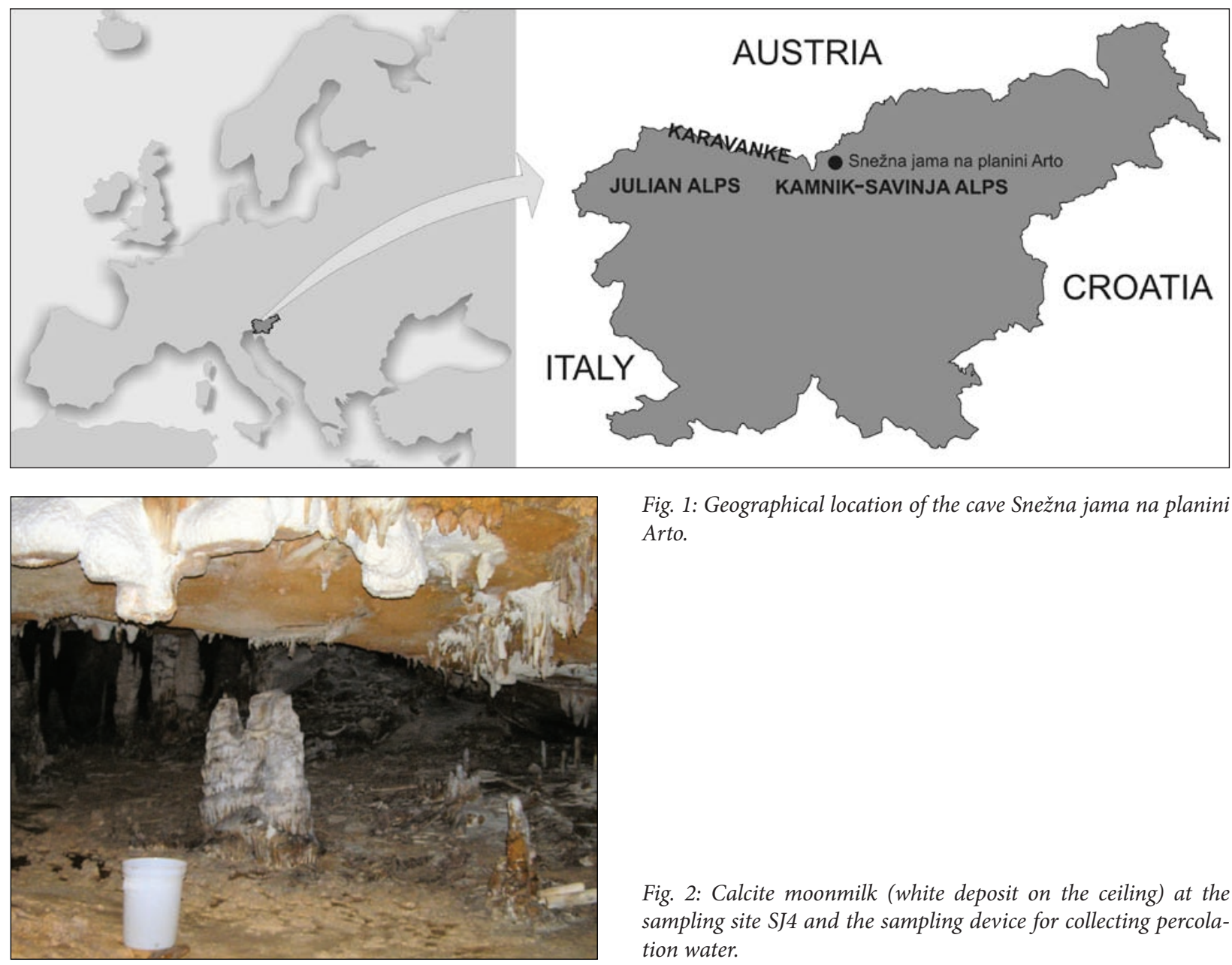

Fig. 1: Geographical location of the cave Snežna jama na planini Arto.

Fig. 2: Calcite moonmilk (white deposit on the ceiling) at the sampling site SJ4 and the sampling device for collecting percolation water.

\section{MATERIAL AND METHODS}

Sampling was done using the continuous sampling device for collecting epikarst fauna developed by Pipan (2003, 2005). Five such devices were placed under dripping water in the cave (Fig. 3). The first of these (SJ1) was $50 \mathrm{~m}$ from the entrance, close to the ice-pillar. This sampling site was more or less covered by ice during the whole sampling period (Fig. 4). Another device (SJ2) was set $100 \mathrm{~m}$ from the entrance; in January it was covered by ice, too. The third sampling site (SJ3) was on the edge of the ice limit in the cave, $270 \mathrm{~m}$ from the entrance. Two collecting devices were positioned in the inner part of the cave: one under the moonmilk, $440 \mathrm{~m}$ from the entrance (SJ4), and the other on a stalagmite, close to the moonmilk formation, $510 \mathrm{~m}$ from the entrance (SJ5) (Fig. 2).

Sampling devices were set in September (except SJ3 which was set in December) 2006 and were monitored for fauna on seven visits from October 2006 till
September 2007. The samples of fauna were in situ fixed and stored in $70 \%$ ethanol. Organisms were sorted in the laboratory of the Karst Research Institute Scientific Research Centre of the Slovenian Academy of Sciences and Arts (IZRK ZRC SAZU) in Postojna, using a microscope (Nikon Eclipse 600) and identified in the laboratory of the Natural History Museum of Trieste, using microscopes Leica MZ 16 and Leica DMLB.

Temperature $\left({ }^{\circ} \mathrm{C}\right)$, conductivity $(\mu \mathrm{S} / \mathrm{cm})$ and $\mathrm{pH}$ of percolation water were measured in situ using a conductivity meter (LF 91, WTW), pH meter (323, WTW), and a Combo multi-parameter Hanna Instruments. Measurements were performed during each sampling of fauna between October 2006 and September 2007, with additional measurements in 2010/2011. Drip rates were measured by collecting water under drips in a graduated cylinder for timed intervals. Concentrations of cations 


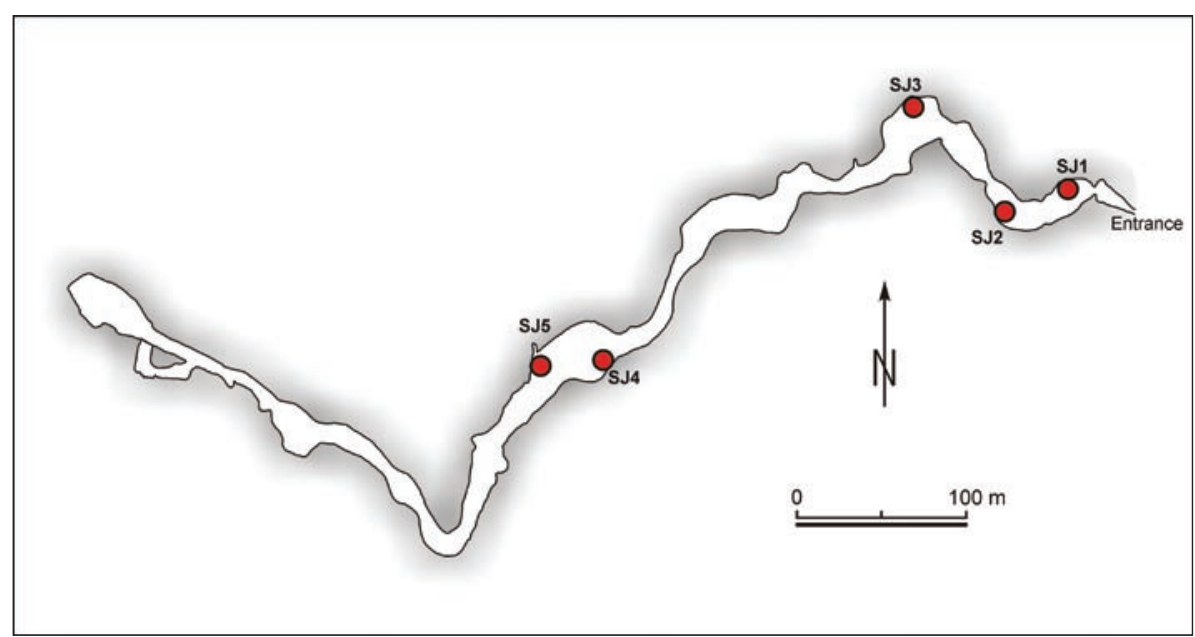

Fig. 3: Map of the cave Snežna jama na planini Arto, with marked locations of sampling sites (modified from Zupan Hajna et al. 2008, used with permission).

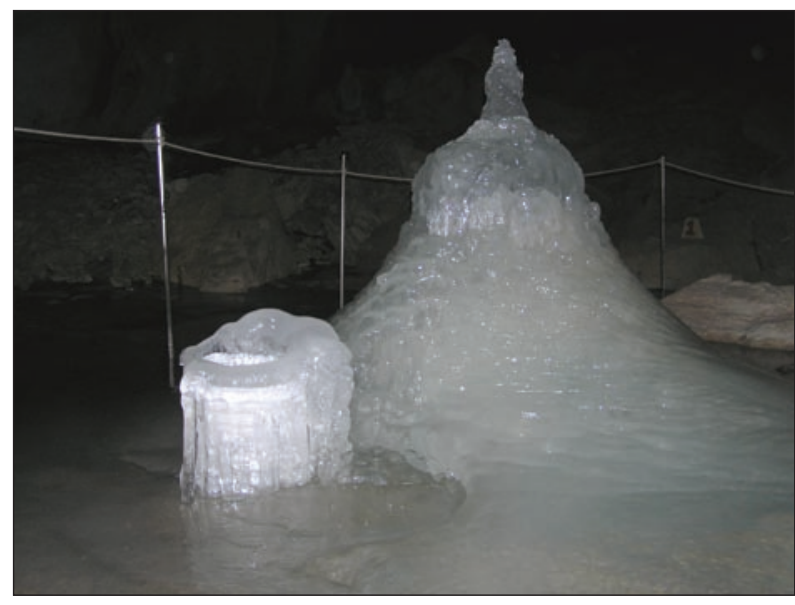

(calcium) and anions (chloride, nitrite, sulphate and phosphate) as well as total hardness were determined periodically according to Standard Methods for the Examination of Water and Wastewater (1989). Measurements at the sampling points SJ1 and SJ2 were not always possible because of periodical ice covering of the sites without liquid water (Fig. 4).

Descriptive statistics was used to describe physical and chemical characteristics of the drips. Pearson correlation coefficients $(r)$ were calculated to evaluate copepod abundances with respect to chemical and physical parameters. Statistical analysis and significance of environmental variables was tested using PAST (Paleontological Statistics Software Package for Education and Data Analysis, version 2.10) (Hammer et al. 2001).

Fig 4: Sampling site SJ1 covered by ice.

\section{RESULTS}

Characteristics of the measured physical and chemical parameters of dripping water in the cave are shown in Tab. 1. Among these, temperature and $\mathrm{pH}$ were the most stable parameters. In both cases, low standard deviation indicates that $\mathrm{pH}$ and temperature values tend to be close to the mean and did not vary among drips or during the sampling period. Temperature of the water among sites varied from $0.0^{\circ} \mathrm{C}$ (frozen water at SJ1 in October) to $4.7^{\circ} \mathrm{C}$ (at SJ5 in December). More variable was discharge, with data spread over a large range of values (e.g., between $0 \mathrm{ml} / \mathrm{min}$ and $880 \mathrm{ml} / \mathrm{min}$, measured in December 2006 at two drips). Dry periods with low discharge were in summer, reflecting no or low amount of precipitation, and in winter because of the snow cover.
A total of 189 copepods, including nauplia, belonging to two species (Speocyclops infernus and Bryocamptus sp.) were collected (Tab. 2). Most cyclopoids (Speocyclops infernus) were recorded at the beginning of summer (in June), while harpacticoids (Bryocamptus sp.) were most abundant in June and in September (Fig. 5). Both species showed some modifications to subterranean life, including depigmentation, reduction of eyes, and appendages elongation. Copepods were found in three of five drips, in 17 of 28 samples (Tab. 3). In addition to copepods, 28 other invertebrates, representing at least eight species were found. Copepods were the most abundant animal group, representing $87 \%$ of all collected animals, and about $90 \%$ of all troglomorphic animals; beside copepods, these were Amphipoda, Hydracarina and Collem- 
Tab. 1: Ranges of physical and chemical measurements of five drips in Snežna jama na planini Arto in 2006-2007 and $2010-2011$. Drips with copepods are italicized.

\begin{tabular}{|c|c|c|c|c|c|}
\hline $\begin{array}{l}\text { Parameter / Drip } \\
\text { Mean } \pm S D \\
(\min -\max )\end{array}$ & SJ1 & SJ2 & SJ3 & SJ4 & SJ5 \\
\hline \multirow{2}{*}{$\begin{array}{l}\text { Temperature } \\
\left({ }^{\circ} \mathrm{C}\right)\end{array}$} & $0.1 \pm 0.2$ & $1.1 \pm 0.8$ & $1.7 \pm 0.5$ & $3.1 \pm 0.3$ & $4.2 \pm 0.3$ \\
\hline & $(-0.3-0.3)$ & $(0.0-2.0)$ & $(0.9-2.4)$ & $(3.1-4.2)$ & $(3.6-4.7)$ \\
\hline \multirow{2}{*}{$\begin{array}{l}\text { Conductivity } \\
(\mu \mathrm{S} / \mathrm{cm})\end{array}$} & $311.0 \pm 5.6$ & $307.0 \pm 32.4$ & $260.3 \pm 32.9$ & $321.7 \pm 10.8$ & $294.1 \pm 19.1$ \\
\hline & $(306.0-317.0)$ & $(243.0-330.0)$ & $(223.0-302.0)$ & $(309.0-346.0)$ & $(266.0-329.0)$ \\
\hline \multirow{2}{*}{$\mathrm{pH}$} & $8.41 \pm 0.33$ & $8.35 \pm 0.29$ & $8.23 \pm 0.32$ & $8.36 \pm 0.25$ & $8.19 \pm 0.23$ \\
\hline & $(8.17-8.79)$ & (7.93-8.78) & $(7.73-8.58)$ & $(7.97-8.82)$ & $(7.97-8.82)$ \\
\hline \multirow{2}{*}{$\begin{array}{l}\text { Discharge } \\
(\mathrm{ml} / \mathrm{min})\end{array}$} & $4.5 \pm 6.4$ & $3.4 \pm 5.0$ & $81.6 \pm 111.7$ & $18.8 \pm 22.6$ & $287.0 \pm 343.7$ \\
\hline & $(0.0-14.8)$ & $(0.0-14.4)$ & $(12.4-300.0)$ & $(5.2-60.0)$ & $(32.0-880.0)$ \\
\hline \multirow{2}{*}{$\begin{array}{l}\text { Total hardness } \\
\text { (mg/L) }\end{array}$} & $178.5 \pm 9.9$ & $164.5 \pm 13.4$ & $144.0 \pm 19.4$ & $174.0 \pm 13.4$ & $162.5 \pm 16.4$ \\
\hline & $(171.5-185.5)$ & $(174-155)$ & $(118.0-162.5)$ & $(187.0-155.5)$ & $(140.0-178.0)$ \\
\hline \multirow{2}{*}{$\begin{array}{l}\text { Ca hardness } \\
\text { (mg/L) }\end{array}$} & $62.12 \pm 7.36$ & $38.65 \pm 18.33$ & $54.66 \pm 5.89$ & $55.60 \pm 3.14$ & $55.63 \pm 3.27$ \\
\hline & $(56.92-67.32)$ & $(25.69-51.61)$ & $(47.33-60.38)$ & $(53.04-60.18)$ & $(52.43-58.55)$ \\
\hline \multirow{2}{*}{$\begin{array}{l}\mathrm{Cl}^{-} \\
(\mathrm{mg} / \mathrm{L})\end{array}$} & $2.0 \pm 0.0$ & $2.5 \pm 0.7$ & $2.12 \pm 0.63$ & $1.87 \pm 0.25$ & $2.12 \pm 0.25$ \\
\hline & $(2.0-2.0)$ & $(2.0-3.0)$ & $(1.5-3.0)$ & $(1.5-2.0)$ & $(2.0-2.5)$ \\
\hline \multirow{2}{*}{$\begin{array}{l}\mathrm{NO}_{3}^{-} \\
(\mathrm{mg} / \mathrm{L})\end{array}$} & $2.54 \pm 0.37$ & $2.54 \pm 0.96$ & $1.91 \pm 0.34$ & $2.88 \pm 0.68$ & $2.43 \pm 0.52$ \\
\hline & $(2.27-2.80)$ & $(1.86-3.22)$ & $(1.51-2.19)$ & $(2.41-3.88)$ & $(1.94-3.12)$ \\
\hline \multirow{2}{*}{$\begin{array}{l}\mathrm{SO}_{4}^{2-} \\
(\mathrm{mg} / \mathrm{L})\end{array}$} & $4.02 \pm 2.19$ & $1.38 \pm 1.15$ & $1.98 \pm 1.11$ & $3.05 \pm 2.19$ & $3.72 \pm 1.50$ \\
\hline & $(2.48-5.57)$ & $(0.57-2.19)$ & $(0.44-3.04)$ & $(0.07-4.93)$ & $(2.04-5.66)$ \\
\hline \multirow{2}{*}{$\begin{array}{l}\mathrm{PO}_{4}^{3-} \\
(\mathrm{mg} / \mathrm{L})\end{array}$} & $0.009 \pm 0.001$ & $0.010 \pm 0.008$ & $0.006 \pm 0.011$ & $0.076 \pm 0.125$ & $0.011 \pm 0.012$ \\
\hline & $(0.009-0.010)$ & $(0.004-0.016)$ & $(0.000-0.023)$ & $(0.000-0.220)$ & $(0.000-0.028)$ \\
\hline \multirow{2}{*}{$\begin{array}{l}\text { Carbonate } \\
\text { (meq/L) }\end{array}$} & $3.34 \pm 0.0$ & $2.73 \pm 0.0$ & $2.64 \pm 0.26$ & $3.27 \pm 0.22$ & $2.96 \pm 0.15$ \\
\hline & $(3.34-3.34)$ & $(2.73-2.73)$ & $(2.46-2.83)$ & $(3.12-3.43)$ & $(2.86-3.07)$ \\
\hline
\end{tabular}

Tab. 2: List of taxa, their abundance and level of specialization to subterranean environment, collected from three drips in Snežna jama na planini Arto in 2006-2007.

\begin{tabular}{|c|c|c|c|c|c|c|c|}
\hline $\begin{array}{l}\text { Phylum / } \\
\text { Subphylum }\end{array}$ & Class / Sublass & Order & Family & Genus & $\begin{array}{l}\text { Troglo- } \\
\text { morphic }\end{array}$ & $N$ & $\begin{array}{l}\text { Sampling } \\
\text { site }\end{array}$ \\
\hline Annelida & Oligochaeta & & & & No & 2 & SJ5 \\
\hline $\begin{array}{l}\text { Arthropoda / } \\
\text { Chelicerata }\end{array}$ & Arachnida / Micrura & $\begin{array}{l}\text { Acarina: } \\
\text { Hydracarina }\end{array}$ & & & Yes & 14 & SJ2, SJ3, SJ5 \\
\hline \multirow{4}{*}{$\begin{array}{l}\text { Arthropoda / } \\
\text { Crustacea }\end{array}$} & \multirow{3}{*}{$\begin{array}{l}\text { Maxillopoda / } \\
\text { Copepoda }\end{array}$} & Cyclopoida & Cyclopidae & $\begin{array}{l}\text { Speocyclops } \\
\text { infernus }\end{array}$ & Yes & 69 & SJ2, SJ3, SJ5 \\
\hline & & Harpacticoida & Canthocamptidae & Bryocamptus sp. & Yes & 112 & SJ2, SJ3, SJ5 \\
\hline & & nauplia & & & & 8 & SJ2, SJ3, SJ5 \\
\hline & $\begin{array}{l}\text { Malacostraca / } \\
\text { Eumalacostraca }\end{array}$ & Amphipoda & Niphargidae & Niphargus sp. & Yes & 3 & SJ5 \\
\hline \multirow{5}{*}{$\begin{array}{l}\text { Arthropoda / } \\
\text { Hexapoda }\end{array}$} & Entognatha & Collembola & Isotomidae & & Yes & 3 & SJ3, SJ5 \\
\hline & \multirow{4}{*}{ Insecta } & Coleoptera & cf. Lathriidae & & No & 1 & SJ3 \\
\hline & & Diptera & & & No & 1 & SJ5 \\
\hline & & Psocoptera & & & No & 3 & SJ2, SJ3 \\
\hline & & Thysanoptera & & & No & 1 & SJ3 \\
\hline
\end{tabular}


bola, the last taxon being terrestrial. Amphipods were found at only one site: SJ5, with the highest temperature and discharge measured. In the sites SJ1 and SJ4 no animals were found (Tab. 3). values of carbonate (over $3.3 \mathrm{meq} / \mathrm{L}$; SJ4), and, of course, in frozen drips. The highest abundance of Copepoda and the other two troglomorphic taxa (Hydracarina and Collembola) were found at the sampling site SJ3 with relatively low temperatures (up to $2.4^{\circ} \mathrm{C}$ ), low conductivity (up to $302 \mu \mathrm{S} / \mathrm{cm}$ ) and low values of carbonate ions (up to $2.8 \mathrm{meq} / \mathrm{L}$ ) in comparison with the other sites. Among the ten variables measured, temperature, conductivity, and total hardness best explained the variation of copepod abundance at the sampling site SJ3. Statistical significant correlations ( $p<0.01$ ) were found between these environmental parameters and the copepod abundance.

In general, Pearson correlation coefficients show significant correlation between copepod abundance and both discharge and $\mathrm{pH}$ ( $\mathrm{r}=0.90, \mathrm{p}<0.05$ in both cases). There was also significant correlation between number of copepod individuals and temperature $(\mathrm{r}=0.75, \mathrm{p}<0.05)$.

We found both mature and immature individuals, first represented by males with mature spermatophore and females with attached spermatophore, as well as many juveniles (38\% of the total copepod abundance) and nauplia (4\% of the total copepod abundance). We did not find any pre-copulating pairs and only one ovigerous female of Speocyclops infernus. The abundance of mature individuals (males and females with mature attached spermatophores) was highly correlated with temperature $(\mathrm{r}=0.8, \mathrm{p}<0.05)$.

\section{DISCUSSION}

Snežna jama na planini Arto is an alpine ice cave, where the alpine climate could limit the distribution of subterranean fauna. Aquatic species (Copepoda, Amphipoda, and Hydracarina) from epikarst water show troglomorphic characters and are presumably troglobionts sensu stricto (Pipan 2005; Pipan et al. 2008; Culver et al. 
2010). Perhaps individuals of Psocoptera and Diptera are accidentals and flew into the traps from the cave, while the other terrestrial taxa (Oligochaeta, Coleoptera and Collembola) might be specialists of the soil root zone (T. Novak, per. comm.). Terrestrial species that are presumably from the root layer also dominated in percolation water in a cave from isolated karst in north eastern Slovenia (Pipan et al. 2008), but not in caves in the Dinaric karst of Slovenia (Pipan 2005). It is not surprising that aquatic and terrestrial species show different patterns of distribution and abundance with respect to karst region (i.e., Dinaric, alpine, and isolated). The factors driving the groups to colonize subterranean habitats are different in the two cases. The Messinian salinity crisis, affecting primarily the Dinaric karst, was a major factor in the colonization of subterranean habitats by aquatic species (Culver \& Pipan 2010), while drying conditions during the Pleistocene were a major factor in the colonization of subterranean habitats by terrestrial species, especially in the northern karst regions (Barr 1968). Nevertheless, the flux of copepods measured as copepod abundance per drip per day was lower in six caves in Dinaric karst (0.1) than in Snežna jama na planini Arto (0.2). This difference is negligible in comparison with data from Organ Cave, West Virginia, USA (Pipan et al. 2006), where an average of one copepod per drip per day was found. It is possible that Dinaric epikarst is less conducting, where the residence time of water may be much greater than epikarst in the other two cases, based on residence time estimates of Kogovšek (2010).

Aquatic as well as terrestrial invertebrates in percolation water are important and sometimes, together with dissolved and fine particulate organic matter, the only source of organic nutrients for organisms in deeper subsurface habitats, especially so in areas of barren surface landscape such as high mountain karst. Simon et al. $(2003,2010)$ showed that the dissolved organic carbon in percolating water was an important carbon source and an important source of epilithic biofilms in caves.

In all five sampled drips a large variation with respect to presence/absence and abundance of copepods was detected as a considerable spatial variation in both physical and chemical parameters. At the most abundant drip, SJ3, three environmental parameters: temperature, conductivity and total hardness of percolation water were found to affect the presence of copepods. In general, values of these parameters were lower in comparison to other drips. Copepods preferred lower temperatures and lower conductivity values, which correspond to lower concentration of calcium and magnesium ions. As the conductivity might be interpreted as a surrogate for the duration of water retention in underground habitats, these results suggest that SJ3 drip is quickly transmitted through the vadose zone. Such circumstances, in general, appear at thinner cave ceilings and/or more fractured bedrock above the ceiling.

Yield of copepods from drips was clearly connected with the flow rate: greater the flow is, greater is the abundance. The presence of amphipods in SJ5 can also be understood as the consequence of a greater flow. This is in contrast to previous investigations in Organ Cave, USA (Pipan et al. 2006), where the highest density of copepods was found at low flow rates. But drip rates in Snežna jama na planini Arto rarely reached $100 \mathrm{ml} / \mathrm{min}$, which was the case in Organ Cave. Upon the data from Snežna jama na planini Arto we can conclude that both, the higher and the slower the flow rates are, the less suitable the epikarst habitat may be for copepods and other microinvertebrates. This could be generally true in the alpine epikarst.

In the epikarst above Snežna jama na planini Arto the optimum conditions appeared in late summer when the highest overall copepod abundance, and the highest abundance of mature individuals were observed in the cave. Accordingly, the abundance of mature individuals was positively correlated with temperature. The absence of fauna in two drips may be explained in two different ways. While SJ1 drip seems sterile because of low water temperature, or possibility of existence deep fissures but with less storage, it is possible that the absence in SJ5 is the consequence of a thick moonmilk deposition which acts as a filter prevailing fauna from falling into the sampling device. The other reason might be some substance noxious to fauna, such as those known to inhibit microbial activity in the moonmilk deposits (Janices et al. 2009). Moonmilk is a secondary cave deposit, commonly associated with biogenic calcite precipitation (Hill \& Forti 1997; Walochnik \& Mulec 2009).

The high proportion (38\%) of immature individuals of copepods is in accordance with data obtained from six caves in the Dinaric karst (Pipan et al. 2010). In both cases, the ratios of immature individuals show that reproduction in situ is high and that the epikarst harbors this troglobiotic fauna. Animals found in drips represent a biased sample of individuals washed out from the substrates in the epikarst where they lived. Anyway, alpine epikarst, where climatic conditions are much more severe than those in lower karst landscapes, is also relatively abundantly colonized with subterranean fauna, like the Dinaric epikarst. Investigations of the alpine epikarst fauna, inhabiting shallow subterranean habitats, might facilitate the understanding of the ecology of the epikarst faunas and their roles within the large range of thermally and otherwise different shallow subsurface habitats. 


\section{ACKNOWLEDGEMENTS}

We are indebted to David C. Culver and Tone Novak for the revision of the manuscript, many useful suggestions and discussions. David Culver and Trevor Shaw improved the language. This study was partly supported by the Slovenian Research Agency, and Ad-futura: Slovene Human Resources Development and Scholarship Fund. Laboratory work was performed at the Karst Research Institute ZRC SAZU and in the entomology laboratory of the Natural History Museum of Trieste. We thank Mateja Zadel for chemical analysis and dr. Andrea Colla for helping at insect determinations, useful suggestions and technical support. FP also thanks the members of Jamarsko Društvo Črni galeb Prebold (especially Darko Naraglav), cavers of Jamarsko Društvo Sežana (especially Jure Jakovščič, Zdenka, Rok and Irena Žitko, Andrej, Luka and Silvia Peca), researchers of the Karst Research Institute ZRC SAZU (especially Janez Mulec and Trevor Shaw), and other friends (Chiara Focaccetti, Fabio Polese, Andreea Oarga, Brane Koren and Brigitta Slavec).

\section{REFERENCES}

Audra, P., Bini, A., Gabrovšek, F., Häuselmann, F., Hobléa, F., Jeannin, P.Y., Kunaver, J., Monbaron, M., Šušteršič, F., Tognini, P., Trimmel, H. \& A. Wildberger, 2007: Cave and karst evolution in the Alps and their relation to paleoclimate and paleotopography.- Acta Carsologica, 36, 1, 53-67.

Barr, T.C., 1968: Cave ecology and the evolution of troglobites.- Evolutionary Biology, 2, 35-102.

Camacho, A.I., Valdecasas, A.G., Rodríguez, J., Cuezva, S., Lario, J. \& S. Sánchez-Moral, 2006: Habitat constraints in epikarstic waters of an Iberian Peninsula cave system.- Annales de Limnologie-International Journal of Limnology, 42, 2, 127-140.

Culver, D.C. \& T. Pipan, 2009: The Biology of Caves and Other Subterranean Habitats.- Oxford University Press, pp. 254, Oxford, U.K.

Culver, D.C. \& T. Pipan, 2010: Climate, abiotic factors, and the evolution of subterranean life.- Acta Carsologica, 39, 3, 577-586.

Culver, D.C., Holsinger, J.R., Christman, M.C. \& T. Pipan, 2010: Morphological differences among eyeless amphipods in the genus Stygobromus dwelling in different subterranean habitats.- Journal of Crustacean Biology, 30, 68-74.

Ford, D. \& P. Williams, 2007: Karst hydrogeology and geomorphology.- John Wiley \& Sons, pp. 562, New York.

Gams, I., 1960: On the extreme upper limit of rural settlements, winter wheat, forest and snow line in Slovenia.- Geografski vestnik, 32, 59-69.

Habič, P., 1969: Hidrografska rajonizacija krasa v Sloveniji.- Krš Jugoslavije, 6, 79-91.
Hammer, Ø., Harper, D.A.T. \& P.D. Ryan, 2001: PAST: Paleontological Statistics Software Package for Education and Data Analysis.- Paleontologia Electronica, 4, 1, 1-9.

Hill, C. \& P. Forti, 1997: Cave minerals of the world.- National speleological society, pp. 463, Huntsville.

Janices, I., Portillo, M.C., Cuezva, S., Gonzales, J.M., Cańaveras, J.C. \& S. Sanchez-Moral, 2009: Microbially induced calcitic moonmilk deposits lead to inhibition of microbial activity in caves.- $15^{\text {th }}$ International Congress of Speleology, Kerrville, Texas, United States of America, July 19-26, 2009. pp. 378, Kerrville, Texas.

Knez, M. \& A. Kranjc, 2009: Kras.- In: Pleničar, M., Ogorelec, B. \& M. Novak (eds.), The Geology of Slovenia. Geološki zavod Slovenije, pp. 561-574, Ljubljana.

Kogovšek, J., 2010: Characteristics of percolation through the karst vadose zone.- Založba ZRC/ZRC Publishing, pp. 168, Postojna-Ljubljana.

Kranjc, A.A., 1984: Speleological characteristics of alpine karst in Slovenia, northwestern Yugoslavia.- Norsk Geografisk Tidsskrift, 38, 3-4, 177-183.

Kunaver, J., 1983: Geomorpholy of the Kanin mountains with special regard to the Glaciokarst.- Geografski zbornik, 22, 201-344.

Moldovan, O.T., Pipan, T., Iepure, S., Mihevc, A. \& J. Mulec, 2007: Biodiversity and ecology of fauna in percolating water in selected Slovenian and Romanian caves.- Acta Carsologica, 36, 493-501.

Novak, T. \& V. Kuštor, 1983: The ecology of an Alpine ice cave.- Mémoires de Biospéologie, 10, 117-125. 
Novak, T., Lipovšek Delakorda, S., Senčič, L., Pabst, M.A., \& F. Janžekovič, 2004: Adaptations in phalangiid harvestmen Gyas annulatus and G. titanus to their preferred water current adjacent habitats.Acta Oecologica, 26, 45-53.

Pipan, T., 2003: Ekologija ceponožnih rakov (Crustacea: Copepoda) v prenikajoči vodi izbranih kraških jam.$\mathrm{PhD}$ thesis (in Slovene with English abstract and summary), Univerza v Ljubljani, Oddelek za biologijo, pp. 130, Ljubljana.

Pipan, T., 2005: Epikarst - A Promising Habitat. Copepod fauna, its diversity and ecology: a case study from Slovenia (Europe).- Karst Research Institute at ZRC SAZU/ZRC Publishing, pp. 101, Postojna.

Pipan, T. \& D.C. Culver, 2005: Estimating biodiversity in the epikarstic zone of a West Virginia cave.- Journal of Cave and Karst Studies, 67, 2, 103-109.

Pipan, T., Christman, M.C. \& D.C. Culver, 2006: Dynamics of epikarst communities: microgeographic pattern and environmental determinants of epikarst copepods in Organ Cave, West Virginia.- American Midland Naturalist, 156, 75-87.

Pipan, T., Navodnik, V., Janžekovič, F. \& T. Novak, 2008: Studies of the fauna of percolation water of Huda luknja, a cave in isolated karst in northeast Slovenia.- Acta Carsologica, 37, 1, 141-151.

Pipan, T. Holt, N. \& D.C. Culver, 2010: How to protect a diverse, poorly known, inaccessible fauna: identification and protection of source and sink habitats in the epikarst.- Aquatic Conservation: Marine and Freshwater Ecosystems, 20, 748-755.
Simon, K.S., Benfield, E.F. \& S.A. Macko, 2003: Food web structure and the role of epilithic biofilms in cave streams.- Ecology, 84, 2395-2406.

Simon, K.S., Pipan, T., Ohno, T. \& D.C. Culver, 2010: Spatial and temporal patterns in abundance and character of dissolved organic matter in two karst aquifers.- Fundamental and Applied Limnology, 177, 81-92.

Slapnik, R., 2001: Activity and movements of Zospeum isselianum Pollonera 1886 (Gastropoda, Pulmonata, Carychiidae) in a cave in the Kamniške-Savinjske Alps (Slovenia).- Natura Croatica, 10, 153-162.

Standard Methods for the Examination of Water and Wastewater, $17^{\text {th }}$ edition, 1989.- APHA-AWWAWPCF, pp. 1088.

Walochnik, J. \& J. Mulec, 2009: Free-living amoebae in carbonate precipitating microhabitats of karst caves and a new vahlkampfiid amoeba, Allovahlkampfia spelaea gen. nov., sp. nov.- Acta Protozoologica, 48, 25-33.

Zupan Hajna, N., Mihevc, A., Pruner, P. \& P. Bosák, 2008: Paleomagnetism and magnetostratigraphy of karst sediments in Slovenia.- Založba ZRC/ZRC Publishing, pp. 266, Ljubljana. 